\title{
Microbiology and the Imperatives of Capital in International Agro- Biodiversity Preservation
}

\author{
by Courtney Fullilove*
}

\begin{abstract}
This essay considers the political economy of transnational scientific research based on global collection of biota for laboratory manipulation, focusing on a program to develop pest-resistant wheat using fungal endophytes common in a range of wild but closely related grasses. This effort extends long-standing efforts to commoditize living substances of increasing scope and complexity, and it is supported by efforts to collect and preserve biological diversity. The essay explores how imperatives of capital shape biodiversity as a policy category and determine which forms of life are saved, materially altering our records of life on earth. These newly legible and malleable organisms become more perfect commodities, suitable for standardization and transmutation into finance capital. Yet endophytes are also of interest in part because of their resistance to such control, throwing into sharp relief the reductive imperatives of commoditization while also provoking new ways of justifying capital accumulation and flow. This essay questions the extent to which histories of capitalism and science as conjoined projects rooted in the biological species concept can explain contemporary practices of biodiversity preservation and the microbiological research they support. Microbiological research provides new renderings of life on earth that may challenge or reconfigure metaphors and practices common to capitalism and science.
\end{abstract}

Rumination is a virtue, and ruminants are the unsung heroes of science. Slow and steady, committed to their single purpose, animals are nevertheless always finding things as they graze. Take the Lewis Chessmen, a set of diminutive and apparently bewildered twelfth-century warriors now housed in the British Museum: according to some reports, a cow roaming the shore of the Western Isles of Britain conducted their excavation. The central drama of this essay originates in the accidental poisoning of cattle and sheep. American cattle grazing on certain fescue became ill with fever, rapid breathing, and excessive salivation. Meanwhile, New Zealand sheep grazing on certain ryegrass were

\footnotetext{
* Department of History, Wesleyan University, Middletown, CT 06459; cfullilove@wesleyan.edu. In addition to the Osiris volume workshop at Columbia University in June 2016, I am grateful to the members of the Department III colloquium at the Max Planck Institute for the History of Science in Berlin, Germany, and especially to commentary and questions from David Sepkoski, Dagmar Schäfer, Dan Bouk, and BuYun Chen. This essay also benefits from participation in Matthias Rillig's "Fungal Biology and Ecology" master course at Freie Universität in Berlin.
}

- 2018 by The History of Science Society. All rights reserved. 0369-7827/11/2018-0015\$10.00 
afflicted with the staggers, developing tremors, incoordination, and collapse. Farmers had long lamented the damage to their flocks caused by the disease and associated susceptibility to accident and death. So when researchers in the United States and New Zealand independently traced toxicity to the Epichloe fungal endophyte in the late 1970s and early 1980s, they summarily set about liberating the plant of its affliction. ${ }^{1}$

Removing the endophyte from the plant did improve the health of the animals - but not that of the plants. Without the fungus, the grasses were devoured by pests and battered by the elements. ${ }^{2}$ Clearly, the plant derived benefit from the microorganisms colonizing its tissues. Researchers took note. Over the next two decades, scientists in the United States and New Zealand worked to develop Epichloë endophytes that conferred protective traits on plants without harming animals. ${ }^{3}$ In the United States, Max Q was released for use with tall fescue in 2000. In New Zealand AR 1 was released for use with perennial ryegrass in 2001 . These pasture grasses distinguished themselves by containing endophytic fungi "beneficial" to the plant hosts and their animal consumers. Thus a bevy of commercially bred pasture grasses, and a new research field, were born.

This narrative, suitable for enthusiasts of interspecies agency and serendipity as tropes in the history of science, provides one story of origins for research into fungal endophytes in pasture grasses in the 1980s. This essay provides another kind of exploration, for seeds and plants are not stable objects but contested artifacts, classified according to variable logics of science, heritage, and property. Their utility and value hinges on the conditions of their preservation, circulation, and reproduction: laboratory and field, public and private, commercial and communitarian. In bred pasture grasses, endophytic fungi confer pest resistance and other potential benefits on their hosts. Breeders exploit these benefits to raise fat cattle and sheep. Contemporary researchers aim to replicate these traits in cultivated cereals for human consumption. Since the 1990 s, research has expanded into the beneficial properties of endophytes in a range of plant species consumed by animals and humans, introducing new questions about the potentials and exploitation of microorganisms for human prosperity.

Literally meaning "in" (endo) "plant" ( phyte), an endophyte can be a virus, another plant, a fungus, or bacteria. Although research targets microbes that may aid agriculture, endophytes can range from mutualistic to pathogenic. Fungi constitute major threats to crops but also provide beneficial properties for plant growth and health, important sources of food products, and model organisms for investigating biological questions. ${ }^{4}$ In spite of a now vast body of research on endophytes and their manipulation, however,

\footnotetext{
${ }^{1}$ C. W. Bacon, J. K. Porter, J. D. Robbins, and E. S. Luttrell, “Epichloëtyphina from Toxic Tall Fescue Grasses," Appl. Environ. Microbiol. 34 (1977): 576-81, esp. 576-8; L. R. Fletcher and I. C. Harvey, “An Association of a Lolium Endophyte with Ryegrass Staggers," N. Zeal. Vet. J. 29 (1981): 185-6.

${ }^{2}$ J. H. Bouton, R. N. Gates, D. P. Belesky, and M. Owsley, "Yield and Persistence of Tall Fescue in the Southeastern Coastal Plain after Removal of Its Endophyte," Agron. J. 85 (1993): 52-5; C. P. West et al., "Endophyte Effects on Growth and Persistence of Tall Fescue along a Water-Supply Gradient," Agron. J. 85 (1993): 264-70; A. J. Popay, "Argentine Stem Weevil Response to Variable Endophyte Infection in Grasslands Greenstone Ryegrass," Proc. N. Zeal. Plant Protection Conf. 50 (1997): 69-72.

${ }^{3}$ Linda J. Johnson, Anouck C. M. de Bonth, Lyn R. Briggs, John R. Caradus, Sarah C. Finch, Damien J. Fleetwood, Lester R. Fletcher et al., "The Exploitation of Epichloae Endophytes for Agricultural Benefit," Fungal Diversity 60 (2013): 171-88.

${ }^{4}$ On crop pathogens, see Matthew C. Fisher, Daniel A. Henk, Cheryl J. Briggs, John S. Brownstein, Lawrence C. Madoff, Sarah L. McCraw, and Sarah J. Gurr, "Emerging Fungal Threats to Animal, Plant and Ecosystem Health," Nature 484 (2012): 186-94.
} 
these microorganisms are not fully understood, and the way they interact with different plants is highly variable. ${ }^{5}$

In the following, I present an account of a development program based in New Zealand that aims to create wheat resistant to pests and abiotic stresses through the introduction of fungal endophytes. Cereal endophyte researchers seek wild relatives of wheat harboring specific fungal endophytes beneficial in bred pasture grasses. Research thus relies on the global collection of grasses classified as wild relatives of cereal crops. Subsequently screened for endophytes in the laboratory, these grasses provide material for researchers. Lodged in nationally and internationally managed gene banks at the sponsoring institutions and the countries of origin, the collected seeds remain accessible to researchers worldwide in compliance with the Convention on Biodiversity (1992) and the International Treaty on Plant Genetic Resources (1995). These seeds represent part of an ambitious and often fraught program to preserve world biodiversity against the encroachments of modern agricultural methods, development, conflict, and climate change. ${ }^{6}$

This essay analyzes the political economy of transnational scientific research based on global collection of biota for laboratory manipulation. In historical terms, Linnaean taxonomy devised in the context of European maritime exploration undergirded the definition and production of commodities based on global seeds and plants, and provided the organizing principle for botanic gardens and the gene banks that succeeded them. Reduction of global biodiversity to the commodity form continues to drive research. Yet although microbiota represent the largest proportion of biodiversity on the planet, they are not easily characterized by conventional species concepts derived from Linnaean taxonomy. In contrast to the sexual reproduction of macroorganisms Linnaeus used to order plant species, microorganisms reproduce asexually, transfer genetic material from other microbial communities, and form symbiotic associations with one another. ${ }^{7}$ Inasmuch as fungi and other microorganisms challenge norms of classification and conservation predicated on the species as a reproductively isolated population, international seed banks ordered by plant species make an unlikely home for their research. ${ }^{8}$ In the last thirty years, many research foci have shifted from botanic to fungal

\footnotetext{
${ }^{5}$ For a summary of current research into the properties of endophytic fungi, see Charles W. Bacon and James F. White, "Functions, Mechanisms and Regulation of Endophytic and Epiphytic Microbial Communities of Plants," Symbiosis 68 (2016): 87-98.

${ }^{6}$ Research for this piece entailed participation in seven collecting expeditions targeting pasture grasses and wild relatives of cereal crops in the Caucasus and Central Asia between 2010 and 2016, as well as laboratory site visits and interviews at AgResearch headquarters in Palmerston North, New Zealand, in January 2016. Collection took place in July and August in Armenia and Georgia (2010), Tajikistan (2011), northwest Russia (2013), Kabardino-Balkaria, Adygea, and Karachai-Cherkessia (2014), and Kazakhstan (2015). Participating international institutions were AgResearch (Palmerston North, New Zealand), the Vavilov Research Institute of Plant Industry (VIR, St. Petersburg, Russia), and the International Center for Agricultural Research in the Dry Areas (ICARDA, Aleppo, Syria, and Rabat, Morocco).

${ }^{7}$ Annette Davison, Christine Yeates, Michael Gillings, and Jan de Brabandere, "Microorganisms, Australia and the Convention on Biological Diversity," Biodiversity \& Conserv. 8 (1999): 1399-1415.

${ }^{8}$ On the institutional history of research in molecular biology, see Michael R. Dietrich, "Paradox and Persuasion: Negotiating the Place of Molecular Evolution within Evolutionary Biology," J. Hist. Biol. 31 (1998): 85-111; Bruno J. Strasser and Soraya de Chadarevian, "The Comparative and the Exemplary: Revisiting the Early History of Molecular Biology," Hist. Sci. 49 (2011): 317-36; Carl R. Woese, "How We Do, Don't and Should Look at Bacteria and Bacteriology," in The Prokaryotes, vol. 1, Symbiotic Associations, Biotechnology, Applied Microbiology, ed. Martin Dworkin et al. (New York, 2006), 3-23.
} 
and microbiological taxonomy, and from species to genome as a locus of diversity. ${ }^{9}$ The capacity of gene banks ordered by plant species to encompass microbiological research suggests the ways novel classifications of life and rubrics of diversity can sustain capitalized research and development while remaining governed by conventions and techniques of natural science some four centuries old. ${ }^{10}$

Cereal endophyte research extends long-standing efforts to commoditize living substances of increasing scope and complexity. That is, although research into fungal endophytes could suggest new concepts of value and interdependency, the industrial imperative of research creates path dependency that forecloses such investigations. For all the marvels of the fungal symbiont, the cereal endophyte program primarily aims to build a better wheat plant, and researchers pursue only those fungi that are responsible for conferring pest resistance and abiotic stress tolerance in related grasses. Ironically, collected material supports development efforts that may further attenuate the diversity on which they rely. Imperatives of capital thus shape biodiversity as a policy category and determine which forms of life are saved, materially altering our records of life on earth. In turn, these newly legible and malleable organisms become more perfect commodities, suitable for standardization and transmutation into finance capital.

This bias of selection is a variant of what some historians of science have dubbed "agnotology," or the cultural production of ignorance. ${ }^{11}$ Shaped by the dictates of political economy, researchers pursue topics and methods that reproduce logics of capital accumulation: in the process, they shed other forms and meanings of life. In science and technology studies (STS), these political rationalities have been analyzed as material assemblages of social relations and objects, with the nonhuman exerting as much control as intentional human subjects over the terms of life. ${ }^{12}$ In the past decade, STS scholars have paid special attention to multispecies interactions, and to the ways knowledge produced from them is situated in particular social and economic contexts. ${ }^{13}$ Others have called for renewed or sustained attention to the social and ideological features of networks and institutions that produce or support technoscience. ${ }^{14}$ Hannah Landecker's formulation of the "biology of history" bridges these approaches to political economy

\footnotetext{
9 Two summations of the debate over the locus of biodiversity preservation in species, genome, or ecosystem are provided by Timothy Farnham, "A Confluence of Values: Historical Roots of Concern for Biological Diversity," in The Routledge Handbook of Philosophy of Biodiversity, ed. Justin Garson, Anya Plutynski, and Sahotra Sarkar (New York, 2017), 11-25; and by James Maclaurin and Kim Sterelny, What Is Biodiversity? (Chicago, 2013).

${ }^{10}$ On the persistence of institutional networks and practices in the history of science, see, e.g., Bruno J. Strasser, "Laboratories, Museums, and the Comparative Perspective: Alan A. Boyden's Quest for Objectivity in Serological Taxonomy, 1924-1962," Hist. Stud. Nat. Sci. 40 (2010): 149-82.

${ }^{11}$ E.g., Robert N. Proctor and Londa Schiebinger, Agnotology: The Making and Unmaking of Ignorance (Stanford, Calif., 2008).

${ }^{12}$ Bruno Latour, "One More Turn after the Social Turn: Easing Science Studies into the Non-modern World," in The Social Dimensions of Science, ed. Ernan McMullin (Notre Dame, Ind., 1992), 272-92; Latour, We Have Never Been Modern (Cambridge, Mass., 1991).

${ }^{13}$ Donna Haraway, When Species Meet (Minneapolis, 2008); Haraway, "Situated Knowledges: The Science Question in Feminism and the Privilege of Partial Perspective," Feminist Stud. 14 (1998): 575 99; Heather Paxson and Stefan Helmreich, "The Perils and Promises of Microbial Abundance: Novel Natures and Model Ecosystems, from Artisanal Cheese to Alien Seas," Soc. Stud. Sci. 44 (2014): 165-93; Helmreich, with contributions from Sophia Roosth and Michele Friedner, Sounding the Limits of Life: Essays in the Anthropology of Biology and Beyond (Princeton, N.J., 2015).

${ }^{14}$ See, e.g., Sheila Jasanoff, ed., States of Knowledge: The Co-production of Science and Social Order (London, 2004); Jasanoff and Sang-Hyun Kim, eds., Dreamscapes of Modernity: Sociotechnical Imaginaries and the Fabrication of Power (Chicago, 2015).
} 
and epistemology by focusing on how past practices of science have shaped the material worlds in which today's researchers operate. "At the same time that we now know more," Landecker observes, "we come to inhabit the material future produced by what we thought we knew." Science itself drives biological change. ${ }^{15}$

Yet if the object of microbiology has primarily been to "harness" the "productive or reproductive capacities" of cells "to human intention," as Landecker has argued, endophytes are of interest in part because of their resistance to such control. ${ }^{16}$ Epichloë endophytes require the plant host to survive, and vice versa. They refuse removal from the bodies of their hosts, with which their life cycles are coterminous. Unlike other forms of cell culture, endophytes refuse to "live differently" in space and time. ${ }^{17}$ The fungus's lack of interest in reducibility or its own market value provides an opportunity to examine the drive toward commoditization that fuels international research and development. ${ }^{18}$ The fungal symbiont's way of life throws into sharp relief the reductive imperatives of commoditization. It may also provoke new ways of justifying capital accumulation and flow.

To what extent do histories of capitalism and science as conjoined projects to organize resources help us understand contemporary practices of biodiversity preservation and microbiological research? Theorizations of capitalism as a world system derive power from biological imaginaries, and vice versa. Increasingly, metaphors of industrialization and standardization seem ill fitted to microbiological research, with its orientation toward interdependency and flux. ${ }^{19}$ The essay proceeds along historical and ethnographic lines, moving from a history of nature collection to a study of contemporary laboratory process in microbiology. First, it characterizes the history of natural history collection and species preservation as adjuncts to capitalism as a world system, exploring the transition from Linnaean hierarchical taxonomy to more novel forms of organization in the twentieth-century life sciences. Second, it considers the cereal endophyte development program as a vehicle to understand the material, political economic, and conceptual implications of contemporary biotechnology and agriculture, including transnational flows of research capital and investigation of organisms that supersede established classificatory schemes for global plant genetic resources. In many respects, applied microbiological research represents a new direction in the conception,

${ }^{15}$ Hannah Landecker, "Antibiotic Resistance and the Biology of History," Body \& Soc. 22 (2016): 19-52, on 37. Landecker characterizes the biology of history as "a recursive structure in which knowledge is produced in and through matter that has itself been altered by previous modes of thought" (37).

${ }_{16}$ Hannah Landecker, Culturing Life: How Cells Became Technologies. (Cambridge, Mass., 2010), 1.

${ }^{17}$ Hannah Landecker, "Living Differently in Time: Plasticity, Temporality and Cellular Biotechnologies," Culture Machine 7 (2005), http://www.culturemachine.net/index.php/cm/article/view/26 (accessed 19 July 2017).

${ }^{18}$ I use the term "interest" self-consciously. In studies of capitalism as a human social system, interest typically refers to the self-oriented motives and behaviors of individuals or groups to amass resources. In science and technology studies, interest is more frequently regarded as multisited and operating through structures of problematization, communication, translation, and institutionalization of knowledge and materials. Two influential explorations of these processes are Michel Callon, Some Elements of a Sociology of Translation: Domestication of the Scallops and the Fishermen of St. Brieuc Bay (n.p., 2000); Susan Leigh Star and James R. Griesemer, "Institutional Ecology, 'Translations' and Boundary Objects: Amateurs and Professionals in Berkeley's Museum of Vertebrate Zoology, 1907-39," Soc. Stud. Sci. 19 (1989): 387-420.

${ }^{19}$ On industrial modernity as the paradigm for genetics, see Phillip Thurtle, The Emergence of Genetic Rationality: Space, Time, and Information in American Biological Science, 1870-1920 (Seattle, 2007). 
organization, and research of biological diversity on earth. ${ }^{20}$ Microbiological research provides new renderings of life on earth that may challenge or reconfigure metaphors and practices common to capitalism and science. Does natural diversity defy the reductive logics of capital, or are the latter so malleable that they subsume all forms of natural diversity?

\section{HISTORY OF AGRO-BIODIVERSITY PRESERVATION}

Histories of capitalism and natural science have emphasized their mutual development. European nation-states supported the accumulation of foreign territories, and naturalists supported the classification of mineral and biological resources with an eye to their profit-making potential. ${ }^{21}$ Concepts of nature's diversity emerged in tandem with capitalism as a world system, with Linnaean taxonomy of genus and species fitted to the commodification of flora for the enrichment of nation-states. ${ }^{22}$ From their inception, seed banks were instruments of capital accumulation. Twentieth-century gene banks elaborated the model of European botanic gardens forged through empire. The interest of plant breeders in exploiting global plant genetic resources for twentieth-century agricultural modernization contributed to their ex situ preservation in centralized seed banks. ${ }^{23}$

This long history of biodiversity preservation suggests strong continuities between early modern European maritime exploration and twenty-first-century agricultural research. Even as both are collecting projects of encyclopedic ambition and global scale, they have each remained defined by service to capitalist interests. In the coterminous development of market and nation-state, the commodity is a stable and essential unit pursued for utility and profit, ordering the natural world to support the governance of populations.$^{24}$ In diverse histories of capitalism ranging from Immanuel Wallerstein's world systems theory to Michel Foucault's biopower, the commodity form remains the basis of capitalist development, historically driven by competition between European nation-states. ${ }^{25}$

\footnotetext{
${ }^{20}$ Applied microbiological research builds on the development of microbiology as a discipline in the preceding centuries. See J. Sapp, "The Structure of Microbial Evolutionary Theory," Stud. Hist. Phil. Biol. Biomed. Sci. 38 (2007): 780-95; Sapp, Where the Truth Lies: Franz Moewus and the Origins of Molecular Biology (Cambridge, 1990); Judy Johns Schloegel, From Anomaly to Unification: Tracy Sonneborn and the Species Problem in Protozoa, 1954-1957 (Dordrecht, 1999).

${ }_{21}$ On European botanic gardens and tropical agriculture, see Richard Harry Drayton, Nature's Government: Science, Imperial Britain, and the "Improvement" of the World (New Haven, Conn., 2000); E. C. Spary, Utopia's Garden: French Natural History from Old Regime to Revolution (Chicago, 2000); Richard Grove, Green Imperialism: Colonial Expansion, Tropical Island Edens, and the Origins of Environmentalism, 1600-1860 (Cambridge, 1995).

${ }_{22}$ On the species as commodity form, see Lisbet Koerner, Linnaeus: Nature and Nation (Cambridge, Mass., 2001); Federico Marcon, The Knowledge of Nature and the Nature of Knowledge in Early Modern Japan (Chicago, 2015), 296-7; Staffan Mueller-Wille, "Philosophy of Biology beyond Evolution," Biol. Theory 2 (2007): 111-2.

${ }^{23}$ Tiago Saraiva, "Breeding Europe: Crop Diversity, Gene Banks, and Commoners," in Cosmopolitan Commons: Sharing Resources and Risks across Borders, ed. N. Disco and E. Kranakis (Cambridge, Mass., 2013), 185-212; Marianna Fenzi and Christophe Bonneuil, "From 'Genetic Resources' to 'Ecosystems Services': A Century of Science and Global Policies for Crop Diversity Conservation,” Cult. Agricult. Food Environ. 38 (2016): 72-83.

${ }^{24}$ On the mutual development of nation-state and market, see also Karl Polanyi, The Great Transformation (Boston, 1957).

${ }^{25}$ Immanuel Maurice Wallerstein, The Modern World-System (New York, 1974); Michel Foucault, The Order of Things: An Archaeology of the Human Sciences (New York, 1971).
} 
Structural renderings of capitalism nevertheless have certain limits. Historians confronting the longue durée of economic development have emphasized capitalism's variability and adaptability. Giovanni Arrighi, following Fernand Braudel, made his subject the historical evolution of capitalism, identifying systemic cycles of accumulation and hegemonic transition between nation-states. ${ }^{26}$ According to Arrighi's model, when material expansion reaches a natural limit, interstate competition for mobile finance capital presents the greatest possibility of expansion, and states strive to assert control over global resources through managerial authority and intellectual property rights rather than simple material accumulation. Although Arrighi backdates the origins of capitalism to the mercantile activity of thirteenth- and fourteenth-century Italian city-states, European maritime exploration, territorial acquisition, and surveys of mineral and biological resources in successive centuries constituted a primary phase of material accumulation. Even as Arrighi emphasized geo-economic processes as essential movers of wealth, however, he identified the pairing of finance capital with interstate competition as the primary feature of capitalism. Territory and money capital are in a constant push-pull cycle, mediated by geography, colonialism and its aftermath, and rising inequality in centers of production. ${ }^{27}$

On the face of it, botanical collection is ill-suited to a model such as Arrighi's, which prioritizes financialization as a motor of capitalist development. Yet contemporary biotechnology operates through the fictions of finance, dependent on money capital and redefinition of plant matter as raw material for research and development. While centralized seed banks are the successor institutions to European botanic gardens, they function as reservoirs for research and development possible only through infusions of finance capital, facilitating the technological manipulation of biological material and its subjection to intellectual property rights and commercialization. ${ }^{28}$ Scientific knowledge functions as a form of capital, providing intellectual, technological, and legal instruments for profit-making applications.

While crops have moved with human hosts since their genesis, movement and interdependence escalated dramatically after 1500, as European nation-states invaded, appropriated, and integrated new geographies into maritime trade and plantation agriculture. American agricultural expansion in the eighteenth and nineteenth centuries was one manifestation of a longue durée of plant transfers resulting from human migration, escalated by European maritime activity from the sixteenth century. The purposeful and incidental transfer of plants from Eurasia to America from the sixteenth to eighteenth centuries supported European settler colonies in the Americas and dramatically

\footnotetext{
${ }^{26}$ Giovanni Arrighi, The Long Twentieth Century: Money, Power, and Origins of Our Times (New York, 1994); Arrighi, "The Winding Paths of Capital," New Left Rev. 56 (2009): 61-94; Fernand Braudel, Capitalism and Material Life, 1400-1800 (New York, 1973); Braudel, The Mediterranean and the Mediterranean World in the Age of Philip II (New York, 1972).

${ }^{27}$ Arrighi, The Long Twentieth Century; Arrighi, "The Winding Paths of Capital" (both cit. n. 26). A succinct summary of Arrighi's theory of systemic cycles of accumulation and hegemonic transition is William I. Robinson, "Giovanni Arrighi: Systemic Cycles of Accumulation, Hegemonic Transitions, and the Rise of China," New Polit. Econ. 16 (2011): 267-80.

${ }^{28}$ On the commodity logic of preserving crop wild relatives, see Miguel A. Altieri, M. Kat Anderson, and Laura C. Merrick, "Peasant Agriculture and the Conservation of Crop and Wild Plant Resources," Conserv. Biol. 1 (1987): 49-58; Maywa Montenegro de Wit, "Stealing into the Wild: Conservation Science, Plant Breeding and the Makings of New Seed Enclosures," J. Peasant Stud. 44 (2017): 169212.
} 
altered ecologies on both sides of the Atlantic..$^{29}$ Meanwhile the importation of tropical biota to metropolitan Europe fueled colonial expansion and provided an international infrastructure of nature collection and preservation consisting of ship holds, vented cases, ledgers, naturalists' notebooks, and herbaria. ${ }^{30}$

Systematic collections of dried plants, generally assembled in a file, box, or cabinet, herbaria are one of the most durable forms of documentation and preservation. They originated in travelers' accounts and devotional books, repurposed and expanded for natural history study in sixteenth-century Europe. Like the herbals of earlier centuries, herbaria draw on reclaimed Greek and Latin texts on medicinal plants, as well as contemporary field specimens, but they differ in observing, cataloging, and describing nature for its own sake. Gradually herbaria evolved from memory aids to tools of study and centers of documentation, supplementing an infrastructure of botanic gardens oriented toward transplantation and cultivation. ${ }^{31}$ These organized and expanded sites preserved the labor of collecting linked to European maritime exploration, colony, and empire. The knowledge systems they devised provided the basis for the expansion of commodity culture through transplantation of biota and mass cultivation for international markets.

Modes of resource control originated in plantation agriculture were extended in capitalist forms of labor. Along with rapid industrialization and private property rights in invention, institutions of public agricultural research were handmaidens of capitalist development. ${ }^{32}$ Over the course of the nineteenth century, public research boosted private enterprise through federally consolidated research and development. In the United States, the U.S. Department of Agriculture, land grant colleges, and experiment stations pursued improved seeds, mechanization, and chemical applications on the farm beginning in the 1870s and 1880s. In the economies of scale they supported, farmers filled grain elevators and railroad cars, yoking east to west and producing an agricultural surplus connecting the United States to international markets.

\footnotetext{
${ }^{29}$ On plant movements and human migration, Alfred W. Crosby, The Columbian Exchange: Biological and Cultural Consequences of 1492 (Westport, Conn., 2003); Crosby, Ecological Imperialism: The Biological Expansion of Europe, 900-1900 (Cambridge, 1986). Judith Carney has revised Crosby's rendering of the Americas as neo-Europes by focusing on the purposeful and incidental transplantation of African crops and agricultural knowledge. See Carney and Richard Rosomoff, In the Shadow of Slavery: Africa's Botanic Legacy in the New World (Berkeley and Los Angeles, 2011).

${ }^{30}$ There is a large literature on the history and epistemic practices of the life sciences, including studies of early modern European natural philosophy, classification, and the experimental sciences. Staffan Müller-Wille and Sara Scharf, "Indexing Nature: Carl Linnaeus (1707-1778) and His Fact-Gathering Strategies," in Working Papers on the Nature of Evidence: How Well Do "Facts" Travel?, ed. Jon Adams (Department of Economic History, London School of Economics and Political Science, 2009), http:// eprints.lse.ac.uk/47386/ (accessed 25 July 2018). On practices and institutions of botanical collection, see, e.g., Harold John Cook, Matters of Exchange: Commerce, Medicine, and Science in the Dutch Golden Age (New Haven, Conn., 2007); Paula Findlen, Possessing Nature: Museums, Collecting, and Scientific Culture in Early Modern Italy (Berkeley and Los Angeles, 1994); Londa L. Schiebinger, Plants and Empire: Colonial Bioprospecting in the Atlantic World (Cambridge, Mass., 2004); Jim Endersby, Imperial Nature: Joseph Hooker and the Practices of Victorian Science (Chicago, 2008).

${ }^{31}$ Brian W. Ogilvie, The Science of Describing: Natural History in Renaissance Europe (Chicago, 2006), 139-264.

${ }^{32}$ William Cronon, Nature's Metropolis: Chicago and the Great West (New York, 1991); Margaret W. Rossiter, The Emergence of Agricultural Science: Justus Liebig and the Americans, 1840-1880 (New Haven, Conn., 1975); Deborah Kay Fitzgerald, Every Farm a Factory: The Industrial Ideal in American Agriculture (New Haven, Conn., 2003); Jack Ralph Kloppenburg, First the Seed: The Political Economy of Plant Biotechnology, 1492-2000 (Madison, Wis., 2004); Alan L. Olmstead and Paul Webb Rhode, Creating Abundance: Biological Innovation and American Agricultural Development (New York, 2008).
} 
New breeding methods consolidated monocultural production and hastened the erosion of agro-biodiversity, incidentally inspiring projects to preserve it. Modern agriculture consists of efforts to select and improve plants according to novel rules and systems of organization, including controlled cross-pollination, hybridization, mutation, marker-assisted selection, and genetic modification. Among the most celebrated of these efforts was the development of high-yielding semidwarf hybrids exported to Asia in the 1960s: the "Green Revolution" alternately credited with averting famine on the Indian subcontinent and ushering in an era of unsustainable agricultural practice. ${ }^{33}$

Aiming to build on the alleged successes of this so-called Green Revolution, the Food and Agriculture Organization of the United Nations (FAO) supported programs of agricultural modernization and the free exchange of germplasm between countries for the use of breeders. The Consultative Group on International Agricultural Research (CGIAR) is an international public organization funded by the UN Food and Agriculture Organization, the Rockefeller Foundation, and the World Bank, among others, that oversees fifteen international agricultural research organizations. These include the Center for Maize and Wheat Improvement (CIMMYT) in Mexico, the International Rice Research Institute (IRRI) in the Philippines, and the International Center for Agricultural Research in the Dry Areas (ICARDA). ${ }^{34}$ Since the 1970s, international agricultural research organizations have prioritized preservation initiatives to offset losses of biodiversity, while breeders survey genetically diverse material to produce new seeds tolerant of heat, drought, and salinity.

Biodiversity preservation initiatives continued to support plant-breeding projects fitted to the production of high-yielding cereal crops for large-scale production, ultimately restricting the scope of their commitment. When international agricultural research centers turned their attention to biodiversity loss, it was to argue that public and private breeders should have access to global plant genetic resources: moving seed stocks out of the field and into banks for circulation to countries with the capital to pursue research. ${ }^{35}$ While the 1992 Convention on Biodiversity (CBD) ${ }^{36}$ incorporated varied forms of traditional and indigenous knowledge, its framing in terms of stakeholders nevertheless elevated the interests of those with the most capital: states, biotechnology companies, and large NGOs. The formulation of Trade Related Intellectual Property Rights (TRIPS) at the Uruguay Round of the Global Agreement on Tariffs and Trade (GATT) in 1998 made the supremacy of industry apparent. ${ }^{37}$

Late twentieth-century international agreements in the spheres of nature preservation and economic development support Arrighi's contention that we are in a period of hegemonic transition. The nature of the current hegemonic crisis is less clear, as are the features of the cycle of financial accumulation. Arrighi concurred with Braudel and

\footnotetext{
${ }^{33}$ E.g., Nick Cullather, The Hungry World: America's Cold War Battle against Poverty in Asia (Cambridge, Mass., 2010); John H. Perkins, Geopolitics and the Green Revolution: Wheat, Genes, and the Cold War (Oxford, 1997).

${ }^{34}$ Warren C. Baum, Michael L. Lejeune, and World Bank, Partners against Hunger: The Consultative Group on International Agricultural Research (Washington, D.C., 1986).

${ }^{35}$ Robin Pistorius and International Plant Genetic Resources Institute, Scientists, Plants, and Politics: A History of the Plant Genetic Resources Movement (Rome, 1997).

${ }^{36}$ Aichi Nagoya Protocol on Access and Benefit-Sharing (ABS), adopted 29 October 2010 at the tenth meeting of the Conference of the Parties (COP 10) to the Convention on Biological Diversity (CBD).

${ }^{37}$ On RAFI, see P. R. Mooney, Seeds of the Earth: A Private or Public Resource? (San Francisco, 1983); Cori Hayden, "From Market to Market: Bioprospecting's Idioms of Inclusion," Amer. Ethnol. 30 (2003): 359-71; Hayden, "Taking as Giving: Bioscience, Exchange, and the Politics of Benefit-Sharing," Soc. Stud. Sci. 37 (2007): 729-58.
} 
Joseph Schumpeter's belief that capitalism was quick to adapt to new forms of wealth accumulation..$^{38}$ Further, Arrighi credits Max Weber with the idea that interstate competition for mobile capital creates the conditions for financial expansion that distinguish modern history. ${ }^{39}$ But in the case of twenty-first-century research and development in agriculture and microbiology, the forms of finance are less predictable and traceable to the coffers of individual states. Hegemonic crisis thus facilitates new configurations of capital ancillary to the nation-state as an institution.

Theorists of laissez-faire have embraced the ecosystem as a model of capitalist dynamism, using the metaphor to justify and naturalize the movement of capital. ${ }^{40}$ The invocation of biological metaphors is not novel to the twentieth century. The study of human and natural economies emerged in tandem in Western Europe, and so it is little surprise that economists have turned to the natural sciences for metaphors of human behavior. ${ }^{41}$ Eighteenth-century models of a well-ordered economy made frequent reference to natural hierarchies. Darwin's theory of evolution did not so much upend these ordering impulses as provide a historical reinterpretation of them according to the premise of common descent. Subsequent students of human economy looked to these lessons for inspiration. While some neoclassical economists turned to physics for its embrace of universal laws of motion, others veered toward biology for its approach to the world as an interconnected system. ${ }^{42}$ Alfred Marshall drew inspiration from Darwin's theory of evolution, and perhaps more significantly Herbert Spencer's application of it to human social life. Friedrich Hayek toyed with the application of evolutionary theory to law, politics, and markets. ${ }^{43}$ Since the 1970 s, economists have looked to ecology and population biology for models of competitive behavior. ${ }^{44}$ As with most attempts to apply theories to new objects, however, evolution takes on hazy and metaphorical significance in these models, reverting to the most general and simplified renderings of natural selection emphasizing competition between individuals.

Yet if nature provides evidence of competition between organisms for scarce resources, it just as readily provides examples of interdependence and flux. Characterized by flexible configurations of finance capital, late capitalist forms of research and development mimic the protean forms of diversity and complexity represented by mi-

\footnotetext{
38 Thomas E. Reifer, "Histories of the Present: Giovanni Arrighi and the Long Duree of Geohistorical Capitalism," J. World-Systems Res. 15 (2009): 249-56, on 253.

${ }^{39}$ G. Arrighi, "Financial Expansions in World Historical Perspective: A Reply to Robert Pollin," New Left Rev. 224 (1997): 154-9, on 156.

${ }^{40} \mathrm{On}$ imagery of capital flows as an alternative to industrial organization as descriptive of capitalism, see Philip Mirowski, The Reconstruction of Economic Theory (Boston, 1986); Yuval Yonay, The Struggle over the Soul of Economics: Institutionalist and Neoclassical Economists in America between the Wars (Princeton, N.J., 2001); Margaret Schabas, Natural Origins of Economics (London, 2011).

${ }^{41}$ This conjoined history is emphasized by Margaret Schabas, "The Greyhound and the Mastiff: Darwinian Themes in Mill and Marshall," in Natural Images in Economic Thought, ed. Philip Mirowski (Cambridge, 1994), 322-35.

${ }^{42}$ Camille Limoges and Claude Menard provide a summary of work to date analyzing metaphors from the physical and natural sciences in economic thought, with Philip Mirowski emphasizing the former, and Neil B. Niman the other, analyzing Alfred Marshall's embrace of population biology and evolution for theories of organization. Limoges and Menard, "Organization and the Division of Labor: Biological Metaphors at Work in Alfred Marshall's Principles of Economics," in Mirowski, Natural Images (cit. n. 41), 336-59.

${ }^{43}$ Geoffrey M. Hodgson, "Hayek, Evolution, and Spontaneous Order," in Mirowski, Natural Images (cit. n. 41), 408-50.

${ }^{44}$ Sharon E. Kingsland, "Economics and Evolution: Alfred James Lotka and the Economy of Nature," in Mirowski, Natural Images (cit. n. 41), 231-48.
} 
croorganisms. Metaphors can be turned to many different purposes, and the remainder of the essay explores their operation in one instance of international agricultural research focused on fungal symbionts in wild grasses.

\section{POLITICAL ECONOMY OF TWENTY-FIRST-CENTURY INTERNATIONAL AGRICULTURAL RESEARCH}

As Hannah Landecker has noted, it is never wise to wait for the historians. Ethnography can serve as a proxy for histories of late twentieth-century and twenty-first-century sciences that have yet to be written, illuminating core practices and assumptions at work in the production of new knowledge ${ }^{45}$ The cereal endophyte development program disrupts conventional historiographies oriented toward divisions between nation-states, metropole/periphery, and North/South, revealing more hybrid forms and flows of research capital in international agricultural research. In the following sections I aim to analyze the political economy and technological practices of contemporary international agricultural research, considering how modes of organization fitted to microbiological research provide new metaphors for human economy, and vice versa. First, I discuss the economic organization of the research in question, and specifically, the imperatives of AgResearch as a public-private institution charged with agricultural improvement and biodiversity preservation. Next, I follow a seed from point of collection in the Pamir Mountains of Tajikistan to its progress through AgResearch laboratories in Palmerston North, New Zealand.

The cereal endophyte program is representative of international agricultural research and biodiversity preservation projects in several respects. First, the public-private nature of the collaboration is typical for late twentieth- and early twenty-first-century research and development, much of which is conducted under the aegis of contemporary agro-biodiversity preservation initiatives. Multiple institutions direct the seed-collecting expeditions providing raw material for the cereal endophyte development program. These organizations include the public-private institute of AgResearch (New Zealand), the national gene bank of the Vavilov Research Institute of Plant Industry (VIR, St. Petersburg, Russia), and the international public organization of ICARDA, Aleppo, Syria, and Rabat, Morocco). Funders for each of these institutions consist of international public organizations, philanthropic and private foundations, and for-profit corporations. In spite of drawing money from the same streams, breeding and biodiversity preservation initiatives coexist uneasily. Projects shift between environmentalist and commercial registers, with seeds collected, catalogued, and stored for posterity and immediate research. While the collecting expeditions lodge material at nationally and internationally managed gene banks charged with the preservation of biodiversity, a sample is screened for the presence of Epichloë endophytes at AgResearch in Palmerston North.

In form, AgResearch is a profit-making science institute, but it draws substantial public funding and hosts the national gene bank of New Zealand (the Margot Forde Germplasm Centre) ${ }^{46}$ Nevertheless, its overall movement has been toward increased

\footnotetext{
${ }^{45}$ Landecker, "Living Differently in Time" (cit. n. 17).

${ }^{46}$ General information about the cereal endophyte breeding program is drawn from interviews and observation with breeders and gene bank managers at AgResearch, Palmerston North, New Zealand, in January 2016, including Stuart Card, Anouck de Bonth, Warren Williams, David Hume, Wayne Simpson, Alan Stewart, Phil Rolston, Valerio Hoyos-Villegas, and Suliana Teasdale.
} 
industry and commercial investment. As the balance of AgResearch's funding has shifted in the last twenty-five years, arguments for public funding within the organization have given way to a discussion of whether majority funding should be commercial. In 1992, the same year the Convention on Biodiversity attempted to recognize local communities and indigenous peoples as stakeholders in the preservation of biodiversity, agricultural research in New Zealand was reconfigured in ways that portended its increasing involvement with the private sector. AgResearch was named a Crown Research Institute, and its charter dictated that it return a small profit to its owner, the New Zealand Government, to demonstrate financially viability. Institutional priorities shifted accordingly, as research relied increasingly on industry-good and corporate funding. The cereal endophyte program is exceptional for the amount of nongovernment money it receives, with substantial funding coming from Grain Research and Development Corporation (GRDC) in Canberra, Australia, as well as Grasslandz Technology, a subsidiary of AgResearch charged with investing in the development of plant-based technologies for licensing to commercial companies. Royalties are invested in further research.

Second, the continuation of research depends on foreign germplasm collection and exchange facilitated by networks of international gene banks. This phenomenon is intensified in New Zealand, where a large proportion of the agricultural and forestry industries is based on transplanted biota from Europe, North America and China. Until the mid-twentieth century, New Zealand's agricultural history was coterminous with its status as a colony of Great Britain, producing for international markets. ${ }^{47}$ Moreover, while collecting missions proceed on geographic theories of biological diversity that mute geopolitics, political concerns remain salient for the cereal endophyte team that I have accompanied. Its collection centered in post-Soviet republics characterized by enormous geographic scope and ecological diversity, imperial legacies of cooperation with St. Petersburg, and recent histories of conflict and rural flight. Collectors amass material and raw data in underdeveloped regions that support highly capitalized research in other locales. These conditions raise complex questions about how preservation projects engage with underdeveloped regions that are identified as centers of biodiversity.

Finally, even as international agricultural research is characterized by flexible and geographically far-flung networks of research capital, it remains rooted in European imperial science. In New Zealand, European interests shaped the development of a pasture economy oriented toward meat, wool, and dairy. In fact, it is New Zealand's status as a center of pasture grass breeding that explains its current research into common fungal endophytes in food crops. There, the growth of the pasturing industry, combined with a native deficit of plant diversity suited to consumption by ruminants, stimulated research and development. British immigrants introduced perennial ryegrass for pastures beginning in the nineteenth century. By the late nineteenth century, farmer-breeders selected, sowed, and traded predominantly locally adapted ecotypes of ryegrass derived from European ones. Beginning in the 1930s, government plant breeders led breeding efforts. Since productive temperate grasses were not native to New Zealand, breeding

\footnotetext{
${ }^{47}$ On New Zealand's industry of animal breeding as a British colony, see Rebecca Woods, The Herds Shot Round the World: Native Breeds and the British Empire (Chapel Hill, N.C., 2017); Woods, "From Colonial Animal to Imperial Edible: Building an Empire of Sheep in New Zealand, ca. 1880-1900," Comp. Stud. South Asia, Africa, Middle East 35 (2015): 117-36.
} 
relied on persistent plant introduction efforts, including Mediterranean and Northern European material suited to winter growth. ${ }^{48}$

The current wave of research into cereals and other crops for human consumption builds on the success of endophyte breeding in pasture grasses within the past thirty years, especially in New Zealand. And here we return to our poisoned sheep. When researchers in the late 1970s traced the ryegrass staggers in sheep to the Epichloe fungal endophyte, the most parsimonious approach was to remove the endophyte. But this approach rendered the grass susceptible to pests, especially the Argentine stem weevil. The first attempts to breed pasture grass resistant to the stem weevil, meanwhile, proved toxic to ruminants. While "Endosafe" eliminated the staggers, grazing animals continued to suffer from heatstress. ${ }^{49}$ Endosafe was recalled, and breeders went back to the drawing board.

By the mid-1980s, breeders in New Zealand successfully identified which endophyte strains were toxic and nontoxic to livestock, allowing them to select strains that were resistant to pests without harming ruminants. The resulting endophyte strain, AR 1, lacked the alkaloids toxic to animals but retained the alkaloid peramine, which deters the Argentine stem weevil. For farmers, this solution was superior to prior attempts to dilute animal consumption by sowing clover and other pasture species amid the ryegrass or otherwise physically manage animal intake of toxic endophytes. Newly developed strains, including AR 37, promise resistance to other exotic and native insects such as the black beetle and porina. ${ }^{50}$

Cereal endophyte researchers aim to build on the successes in pasture grasses by extending endophyte research into a range of other crops for animal and human consumption. Extending research to human food plants, however, raises a range of new issues regarding safety and suitability for human consumption. Deliberate and accidental selection of food plants extend backward some 20,000 years, long before the advent of settled agriculture. Needless to say, there is no clear documentary record of these events. Perhaps many fungal endophytes were selected out of the food supply from an early stage of domestication because of their toxicity to human beings. Only within the past few years have researchers managed to form a synthetic association of fungal endophyte strains with cultivated cereal grasses. One may question the wisdom of putting fungi in, or back in; and yet, perhaps, as for cattle and sheep, breeders can find the ones they want and leave the others behind.

Moreover, if endophytes confer environmental hardiness, perhaps understanding these microorganisms can help humans adapt to future climate change. Certain tall fescue and perennial rye grasses have coevolved with symbiotic fungal endophytes that resist environmental stressors, especially pests. In New Zealand, Australia, and the United States, where forage grasses provide the feed for grazing ruminants, selection of these

\footnotetext{
${ }^{48}$ Alan B. Stewart (PGG Wrighton Seeds, Plant Breeding, Christchurch, New Zealand), "Genetic Origins of Perennial Ryegrass (Lolium perenne) for New Zealand Pastures," in Breeding for Success: Diversity in Action, ed. C. F. Mercer, Proceedings of the 13th Australasian Plant Breeding Conference (Christchurch, New Zealand, 2006), 11-20; Stewart, "Progress in Domesticating New Zealand Native Grasses," unpublished paper, in the possession of the author; Riddet Institute, Floreat Scientia: Celebrating New Zealand's Agrifood Innovation (Auckland, 2011).

49 Johnson et al., "The Exploitation of Epichloae Endophytes" (cit. n. 3), 178.

${ }^{50}$ C. A. Young, D. E. Hume, and R. L. McCulley, "Forages and Pastures Symposium: Fungal Endophytes of Tall Fescue and Perennial Ryegrass: Pasture Friend or Foe?," J. Anim. Sci. 91 (2013): 2379 94.
} 
endophytes has benefited pastoral agriculture enormously. ${ }^{51}$ There is also some evidence that toxic endophyte infection promotes water circulation during plant growth, improves recovery after drought, and increases resistance to elevated temperatures: qualities prized in a warming world. ${ }^{52}$

Regardless, the success of endophyte inoculation into pasture grasses does not spell immediate success for comparable advances in cereal crops. The asexual Epichloë (formerly Neotyphodium) endophytes are found widely distributed in populations of the grasses Lolium perenne and Festuca arundinacea. In contrast, fungal endophytes have not been found in cultivated cereals (e.g., wheat, barley, rye), or in close relatives of the wheat plant. It is as yet unclear whether it is possible to produce a consumable cereal hosting pest-resistant endophytes.

Meanwhile, VIR, ICARDA, AgResearch, and assorted post-Soviet gene banks support collecting expeditions across Eurasia, including the post-Soviet republic of Tajikistan. In the section that follows, I track the transit of a seed from a field in Tajikistan to the gene bank and laboratory in Palmerston North during a 2011 expedition to the Pamir Mountains comprised of collectors from AgResearch, ICARDA, VIR, and the Tajik national gene bank. My focus is on the mismatch between protocols of collection and preservation for wild flora and the body of microbiological research they support, and the significance of this rift for the relation between science and capital.

\section{MICROBIOLOGY AND PROBLEMS OF CLASSIFICATION: FIELD, GENE BANK, AND LABORATORY}

The Pamir Mountains of Tajikistan and Afghanistan, identified as a center of biological diversity by the pioneer Russian plant geneticist Nikolai Vavilov in the 1920s, remain a focus of plant genetic resource collection, and a site of collection. Tajikistan, bordered by Afghanistan, Uzbekistan, Kyrgyzstan, and China, is the poorest of the fifteen postSoviet republics, with the lowest GDP, a lack of employment opportunities, and industrial and agricultural production crippled by the civil war of the 1990s. Tajikistan remains dependent on international aid agencies for basic subsistence, and the most active of these agencies is the Aga Khan Foundation, directed by the Aga Khan IV, an international business magnate who is also the imam of the Ismaili Shiites, the majority population in the Pamirs. Agriculture in the area was decimated by conflict. Much of the area has only recently been cleared of land mines, its fields dotted with warning signs and Russian tanks collapsed over embankments. One of the largest sectors of Tajikistan's economy may be the black market traffic in opium from Afghanistan to

\footnotetext{
${ }^{51}$ G. E. Aiken and J. R. Strickland, "Managing the Tall Fescue-Fungal Endophyte Symbiosis for Optimum Forage-Animal Production," J. Anim. Sci. 91 (2013): 2369-78; H. S. Easton, "Ryegrass Endophyte: A New Zealand Grassland Success Story," Proceedings of the Conference-New Zealand Grassland Association 63 (2001): 37-46; J. P. J. Eerens, Kris Miller, J. G. H. White, H. S. Easton, Richard J. Lucas, "Ryegrass Endophyte and Sheep Reproduction," 56th New Zealand Grassland Association Conference, 1994, https://researcharchive.lincoln.ac.nz/handle/10182/4591 (accessed 19 July 2017).

${ }_{52}$ D. E. Hume and J. C. Sewell, "Agronomic Advantages Conferred by Endophyte Infection of Perennial Ryegrass (Lolium perenne L.) and Tall Fescue (Festuca arundinacea Schreb.) in Australia," Crop Pasture Sci. 65 (2014): 747-57; Johnson et al., "The Exploitation of Epichloae Endophytes" (cit. n. 3); David E. Hume, Geraldine D. Ryan, Anaïs Gibert, Marjo Helander, Aghafakhr Mirlohi, and Mohammad R. Sabzalian, "Epichloë Fungal Endophytes for Grassland Ecosystems," Sustainable Agricult. Rev. 19 (2016): 233-305.
} 
neighboring countries: unmarked trucks careen along the roads near the Panj River bordering Afghanistan.

Four days and fourteen sites into the expedition, the collecting team paused for a break in Vitchkut village, in the Gorno-Badakhshan region of Ishkashim, adjacent to some hot springs. While the bulk of the team wandered off to the baths, the team's most dedicated botanist, Josephine Piggin, continued to collect. Among her collection was an alpine species of Hordeum brevisubulatum subsp. turkestanicum, a wild relative of barley. The same species was found five sites later in a mountain pasture near the village of Yazba. Screened a year hence at AgResearch in Palmerston North, the plants from Yazba were found to harbor the fungal endophyte Epichloë, which is responsible for pest resistance in many pasture grasses. ${ }^{53}$ These collections complemented previous collections of Hordeum, Elymus, and other genera found to harbor Epichloë.

Twenty-first-century researchers employ an array of technological practices with long histories. Instruments used to preserve and record plant matter, including herbaria, Linnaean binomials, breed names, and genetic sequences create different grammars for seeds through varied modes of parsing, labeling, and representation. If these are grammars that order natural resources for exploitation and improvement, they convey assumptions about natural and human creativity/agency, and the proper political economy for managing material and intellectual resources. On one hand, the persistence of early modern European collecting practices in contemporary biodiversity preservation projects is an indication of continuity in natural sciences forged to exploit the natural world. The Linnaean binomial is one realization of this universalizing system, maintained into the twenty-first century as the lingua franca of plant scientists, and indeed their only common language. In collecting expeditions staffed by Tajik, Kazakh, Armenian, Georgian, Russian, New Zealand, Greek, and Syrian scientists, we generally bellowed across the field in Latin, condensing a welter of information into a single identifier: Aegilops crassa! Aegilops tauschii! Hordeum brevisubulatum! Bagged, threshed, cleaned, and lodged in a gene bank, a plant's local identity, condensed to its "passport data," becomes subsidiary to the binomial and accession number in the database.

On the other hand, although collecting teams proceed on the basis of plant genus, species, and subspecies, for cereal endophyte researchers, the true objects of investigation are microorganisms within the plant. This mismatch is not unique to cereals endophyte research, or to the twenty-first century. In spite of the entrenchment of Linnaean taxonomy in the practice of collecting and preserving biological diversity, the targets of conservation have long been a matter of dispute. ${ }^{54}$ Even within the purview of population biology, genes and ecosystems vie with species as the locus of conservation. These have received much less attention than the genomes of multicellular organisms

\footnotetext{
${ }^{53}$ Expedition tag TJK11, Site 14, Accession 1, Hordeum brevisubulatum, ssp. turkestanicum, collected 16 August 2011 by Josephine Piggin, Vitchkut, near hot springs, Gorno-Badakhshan, Ishkashim, Tajikistan; Site 19, Accession 1, Hordeum brevisubulatum, ssp. turkestanicum, collected 17 August 2011, Yazba mountain pasture, Gorno-Badakhshan, Ishkashim, Tajikistan.

${ }^{54}$ On foundational concepts of biodiversity preservation, see, e.g., Timothy J. Farnham, Saving Nature's Legacy: Origins of the Idea of Biological Diversity (New Haven, Conn., 2007); Farnham, "A Confluence of Values"; David Sepkoski, "Extinction and Biodiversity: A Historical Perspective," in Garson, Plutynski, and Sarkar, The Routledge Handbook, 26-40; Maclaurin and Sterelny, What Is Biodiversity? (all cit. n. 9). Many argue that a species approach is too narrow, provoked by a popular concern with species extinction and the endangerment of certain flora and fauna. Nevertheless, species remains a proxy for other forms of diversity in contemporary policy.
} 
such as our own, and they suggest that the "tree of life" is something other than what we have imagined. ${ }^{55}$ Ecosystem approaches provide more contextual and holistic approaches to the conceptualization of natural diversity. Detractors observe the difficulty of classifying or preserving individual ecosystems. Many advocate the gene as a more suitable unit of conservation, while others argue that a myopic focus on the genome has attenuated broader and more contextual conceptions of life on earth. Since the 2003 sequencing of the human genome, criticisms of "genocentricism" have abounded, resisting simplistic accounts of evolutionary theory and assertions that genetics can explain complex psychological traits. ${ }^{56}$ Even so, the assumption of a unique relationship between organism and genome has proved tenacious, with the genome acting as a kind of "species 'barcode," "to use John Dupré's term. But as Dupré also observes, such an approach, oriented toward multicellular organisms, does not take into account fungi hosting multiple distinct genomes and capable of moving within and among their hosts.

In practice, species remains a surrogate for other forms of diversity, well-suited to ex situ administration and subsequent subjugation to molecular biological and genetic analysis. In the field, moreover, a knowledge of plant morphology trumps expertise in genetic sequencing or molecular biology, and the tools of the trade remain a magnifying glass, a jeweler's loupe, and a good knife. For all the enthusiasm surrounding the genome as a locus of conservation, one cannot collect without identifying a plant phenotypically, drawing on centuries of work by taxonomists. That is, collectors still have to know which grasses they are looking for, and how a Hordeum marinum compares to a murinum to a brevisubulatum. In expedition vehicles, field guides in multiple languages lie piled on dashboards and wedged between seats and doors. Routinely, collectors cluster around the seats with magnifying glasses, examining whole plants for correct identification. As one collector groups bags by species-subspecies and assigns collecting numbers, another logs each sample's data in a spreadsheet or database, along with passport data for the site consisting of GPS coordinates, regional and local names, aspect, soil $\mathrm{pH}$ and salinity, and collecting area.

Somehow envelopes are always scarce, with cargo reduced to a minimum of camping gear and collecting equipment in the expedition vehicles. It follows that collectors routinely argue over the conservation of envelopes, with one party asserting that all samples of the same plant from a single site be mixed, and others demanding that they remain separate to distinguish phenotypic variation and minimize errors in sampling due to misidentification of species. This argument has recurred in every collecting expedition I have attended, and it has never been successfully resolved, at least not until the team members consumed generous amounts of vodka at campsites. Then, on occasion, the team runs out of packets. Once the collecting team spent two hours in a provincial Russian city searching for replacements. Only the wasted hours not spent collecting, and the late start due to overconsumption of vodka, saved the expedition from running out of envelopes entirely.

The collecting team traveled for a total of six weeks in the Pamir Mountains and river valleys of the Gorno-Badakhshan region of Tajikistan. Afterward, some 900 brown paper bags of seeds from forty-five sites were laid out and filed on the floor of a field shed at the Tajik national gene bank outside the capital city of Dushanbe. Over the course of

\footnotetext{
${ }_{55}^{5}$ John Dupré, Processes of Life: Essays in the Philosophy of Biology (New York, 2012), 116-7.

${ }^{56}$ Barry Barnes and John Dupré, Genomes and What to Make of Them (Chicago, 2008).
} 
four twelve-hour days, the collecting team and three technicians and fieldworkers from the Tajik national gene bank unbagged the seeds and then threshed, cleaned, and divided them among the participating institutions. AgResearch and ICARDA selected seeds in their mandate and target areas, while the Tajik national gene bank retained a duplicate of every collected accession. Finally, 364 samples identified by species and subspecies were logged with "passport data" mandated in an addendum to the Standard Material Transfer Agreement (SMTA) of the 2001 International Treaty on Plant Genetic Resources for Food and Agriculture, the mandatory model for parties who provide and receive material under the Multilateral System. Passport data consist of a persistent, unique numerical identifier, collecting institute codes, country of origin, date of collection, and taxonomic and site data. ${ }^{57}$

For the most part, the existing infrastructure of international gene banks supports the extension of biodiversity preservation programs to explore fungal diversity. This capacity is an indication of the robust and malleable characteristics of international networks of research capital drawing on dispersed governmental, nongovernmental, and corporate coffers, mingling profit-making and utilitarian claims to preserve natural diversity. Nevertheless, the organization of gene banks and international plant genetic resource policies introduces additional obstacles to cereal endophyte research. Gene banks treat accessions with fungicide to maintain plant health and maximize the production of viable seed. Depending on the fungicide and dosage used, a potential and inadvertent side effect is the loss of the endophyte. While the Margot Forde Germplasm Centre uses endophyte friendly fungicides, other institutions may not. Thus researchers cannot rely fully on previously collected material from other gene banks for their investigations.

Moreover, prevailing classificatory systems in internationally managed gene banks fail to represent the complexity of contemporary scientific practice. Currently no national or international plant genetic resource policy is organized to account for microorganisms. Even as microorganisms constitute the greatest share of biodiversity on the planet, the Convention on Biodiversity was drafted with reference to plants and animals. In the entire text of the Convention, the words "microorganism" and "microbial" each appear only once. ${ }^{58}$ Although researchers may identify the gene as the locus of diversity and focus increasing attention on microorganisms and their relations, they retain Linnaean taxonomy to organize their vaults and databases. Moreover, collection depends on the taxonomic identification of the genus, species, and subspecies of a plant. In practice, genotype and phenotype remain tethered.

National laws regarding invasive species and biosafety also complicate collection. Although fungi are the true objects of the cereal endophyte funded collecting expeditions, researchers contend with a policy framework in which "good" diversity of flora is often distinguished from "bad" diversity of pathogens and pests. Even sanctioned projects may run into trouble at national borders, where bureaucrats enforcing regulations against invasive plants, pests, and diseases may confiscate and quarantine collected material. On one collaborative expedition in 2010, Syrian customs blocked ICARDA's

\footnotetext{
57 "Standard Material Transfer Agreement: International Treaty for Plant Genetic Resources for Food and Agriculture (ITPGRFA)," www.wipo.int/tk/en/databases/contracts/texts/smta.html (accessed 19 September 2017); FAO/Bioversity Multi-Crop Passport Descriptors V.2.1, December 2015, https://www .bioversityinternational.org/fileadmin/user_upload/online_library/publications/pdfs/FAOBIOVERSITY _MULTI-CROP_PASSPORT_DESCRIPTORS_V.2.1_2015_2020.pdf.

${ }^{58}$ Davison et al., "Microorganisms" (cit. n. $\overline{7}$ ), $14 \overline{0} 7$.
} 
portion of the collections from Armenia and Georgia. In some cases, specimens are destroyed. Gene bank personnel cringe over a recent instance of Australian customs incinerating unique lichen specimens on loan from France and New Zealand according to biosecurity protocols. ${ }^{59}$ In yet another recent case, the New Zealand Ministry for Primary Industries is the target of a class action suit by kiwifruit growers, who argue that an import of pollen with vine-killing disease would have been prevented had the protocols of the national Biosecurity Act been properly enforced. ${ }^{60}$ The court ruled in favor of the growers. ${ }^{61}$ In this climate, and as journalists politicize agricultural science in debates over genetically modified organisms, researchers leery of misunderstanding may also fail to articulate different kinds of diversity imperative to their investigations.

In some expeditions, seeds are bagged and shipped via DHL or international courier. This creates a certain amount of anxiety on the part of collectors fearing mishandling or destruction of their specimens. The situation may be no different should the collector carry the seeds in his or her checked luggage, but at least he or she can attend the crisis in person. Such interventionism can be to the benefit of the collectors, as when the New Zealand gene bank manager phoned a senior adviser at the Ministry of Primary Industries (MPI) late at night to secure special exemptions for importing seeds for the cereal endophyte project. Although the seeds had not yet been cleaned according to standard biosecurity protocols, the manager was able to arrange their transfer directly into quarantine for final processing under MPI supervision. Anecdotal evidence suggests that not all collectors are so scrupulous. On the collections I have attended, casual talk about circumventing the onerous paperwork and clearance rules has been met with ominous disapproval, with the trigger word being "smuggle." These utterances threaten to cross the porous boundary between biopiracy and multilateral sharing of seeds for international research.

It is easy to see how these parcels could resemble trash or booty. Envelopes used in field collection are repurposed in the ultimate division of samples between sponsoring parties, relabeled in ink with their accession number, gene bank destination, and species-subspecies, and reduced to a minimum size through folding and stapling. Thereafter they are jammed into cloth sacks, again aiming to reduce bulk as much as possible, and then stuffed into collapsible bags or suitcases along with dirty laundry and other artifacts of travel. Safely conveyed from Dushanbe to Palmerston North in the luggage of the New Zealand gene bank manager via transfer through Istanbul, two days in Dubai, and onward flights to Sydney and Auckland, the seeds from Vitchkut and Yazba, along with the rest of the those from Tajikistan, traveled with official permission past the enforcers of New Zealand's biosecurity protocols, and finally to AgResearch facilities in Palmerston North. There, still in their collecting envelopes, now triple folded, stapled, and labeled in permanent marker, the seeds begin another life (fig. 1).

Obligate endosymbionts cannot exist apart from the plant host, but many can be isolated and cultured in the laboratory with standard microbiological techniques. To convey the time- and labor-intensive quality of these techniques, I describe them in some

\footnotetext{
59 “Australian Customs Destroys Unique Lichen Specimens in Quarantine Mix-Up," Sydney Morning Herald, 8 May 2017, http://www.smh.com.au/environment/australian-customs-destroys-unique-lichen -specimens-in-quarantine-mixup-20170508-gw0fui.html.

60 "Class Action Lawsuit over Kiwifruit Psa Outbreak," Newshub, 8 July 2017, http://www.newshub .co.nz/home/money/2017/08/class-action-lawsuit-over-kiwifruit-psa-outbreak.html.

61 "Kiwifruit Growers Claim Victory in High Court Psa Case | Stuff.Co.Nz," https://www.stuff.co.nz /business/farming/105113232/kiwifruit-growers-win-partial-victory-in-high-court (accessed 24 July 2018).
} 

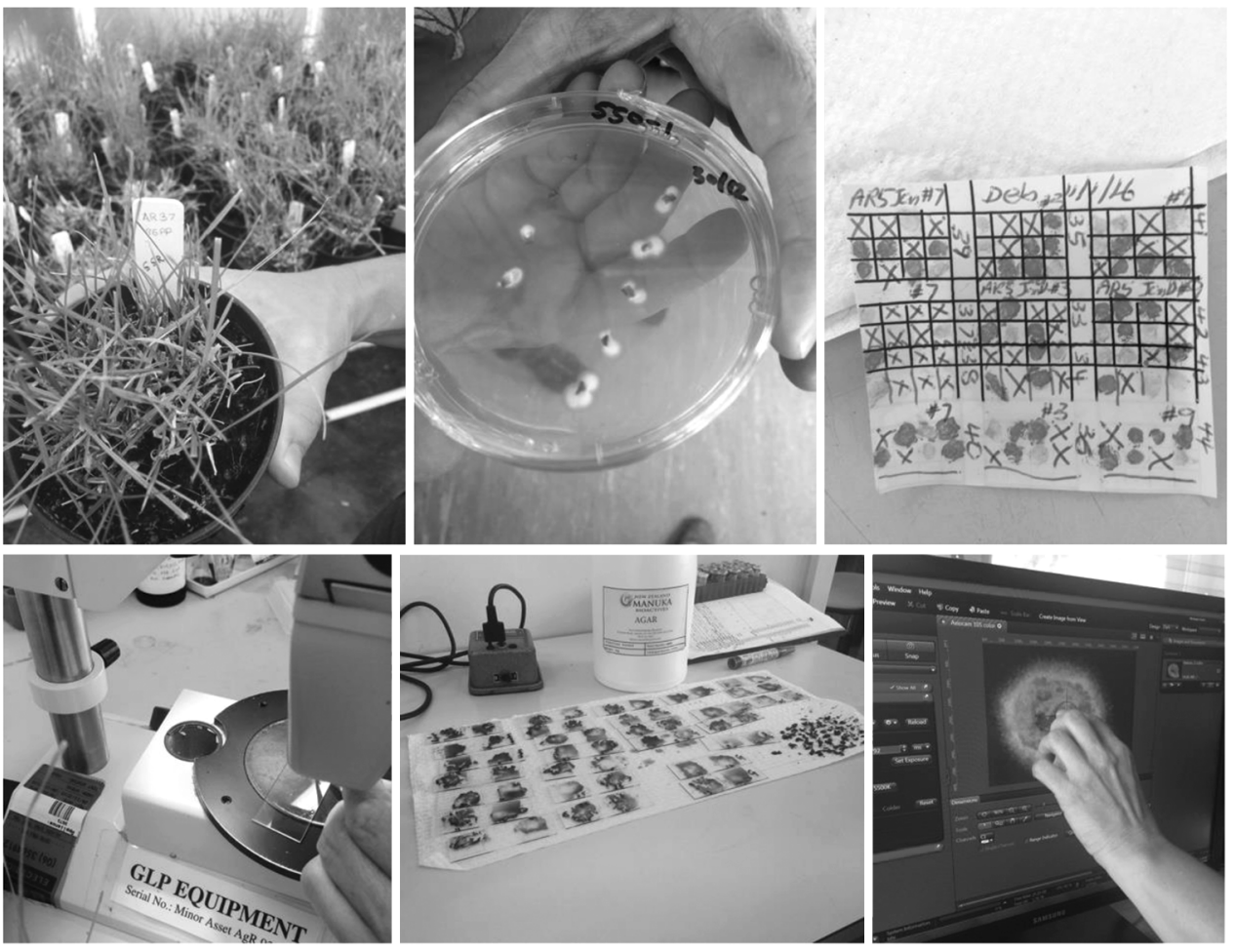

Figure 1. Immunoblot: red chromogen-bound tiller imprints from endophyte-infected plants and unbound imprints from endophyte-free plants (top, left to right); aniline blue stain of infected seedlings using microscopy (bottom, left to right); magnification of fungal endophyte culture, AgResearch, Palmerston North, New Zealand. Photographs by Courtney Fullilove.

detail below. ${ }^{62}$ The seeds collected in the field reach the gene bank in their paper packets, notated with accession number and species-subspecies. Gene bank managers import or key in data from spreadsheets collated in the field, including GPS coordinates, site data, and individual notes on the plant encompassing maturity, habitat, and unusual phenotypic characteristics. While the majority of collected specimens are logged in the Margot Forde Germplasm Centre database, repackaged, and transferred to cold storage vaults, a minority are selected for the working material of the cereal endophyte researchers. These are grown out as seedlings in containment glasshouses, where they are inspected by the MPI for pests and diseases and subjected to further examination.

Researchers use multiple methods for detecting endophytes: epidermal leaf peel, seed squash, and immunoblot detection using rabbit generated antibodies. In a leaf peel, sheath tissue from a live plant is removed and viewed at $16 \times$ magnification, adaxial epidermis up, cut transversely, and mounted on a slide prepared with a drop of

\footnotetext{
${ }^{62} \mathrm{My}$ account of the following techniques is drawn from observation of technicians and partially documented in W. R. Simpson, J. Schmid, J. Singh, M. J. Faville, and R. D. Johnson, "A Morphological Change in the Fungal Symbiont Neotyphodium lolii Induces Dwarfing in Its Host Plant Lolium perenne," Fungal Biol. 116 (2012): 234-40.
} 
aniline blue stain. Heated over a flame, then cooled and reexamined, infected plants display fungal hyphae running along the leaf axis. In a seed squash, grains are covered in sodium hydroxide solution overnight before being decanted, rinsed, covered with an aniline blue solution, and boiled on a hot plate. After cooling, the upper and lower bracts of the floret are discarded and the true seed mounted on a microscope slide with aniline blue and "squashed" gently. In infected plants, stained blue hyphae are visible when examined at $100 \times$ and $400 \times$ magnification under a compound light microscope.

In immunodetection, grass tillers are cut from live plants at soil level, with the freshly cut end placed onto a nitrocellulose membrane. The circular blots left from the imprint form a grid on the nitrocellulose sheet, with positive and negative controls included. Researchers coat blotted sheets with a milk protein-blocking solution, shake them for two hours using miniorbital shakers, decant, rinse twice with more blocking solution, and then add 25 microliters of a solution containing rabbit antibodies to endophytes. Antibodies are the active ingredients in this particular cocktail. After fifteen minutes of shaking, incubation overnight at $4^{\circ} \mathrm{C}$, and another round of decanting and rinsing in blocking solution to remove excess rabbit antibody, a secondary goat antibody solution is added and subjected to similar processing. Ultimately the test blot membrane is immersed in a chromogen solution. Shaken another fifteen minutes, the positive control blot, and any others manifesting infection, turn red. Of all the tests, this is the most rapid and efficient. Results are available immediately. But the immunoblot test also has the highest ratio of false positives, meaning positive results are typically rescreened using another method.

The foregoing are techniques for detecting fungal endophytes in seedlings. Cereal endophyte research also entails techniques for the inoculation of seedlings with isolated fungal endophytes. To isolate the fungi, technicians remove tillers from endophyteinfected grass to a length of around 5 centimeters. They then disinfect the plant tissue in an ethanol rinse, a bleach soak, and two rinses in sterile water. Technicians then section the tillers transversely, with sheath rings plated in a base of antibiotic potato dextrose agar and incubated in the dark for three to five weeks. Seedlings to be inoculated with the fungal endophyte are subjected to a similar regimen, with seeds sterilized in sulfuric acid, water, and bleach before being dried, arranged on Petri plates, and germinated in the dark for five to seven days. Technicians inoculate the seedling with the aid of a microscope and a scalpel, making a narrow slit in the base of the seedling plant and placing cultured mycelium from the infected plant into the incision. After another week in the incubator and another week after that under white fluorescent bulbs, seedlings are planted and grown for six weeks in a glasshouse.

Genetic sequencing is also a usable technique for identifying the presence of fungal endophytes in host grasses. Tillers cut at soil level and transferred to DNA extraction vials are processed using Q-BIOgene FastDNA kits, amplified by PCR (polymerase chain reaction) to identify two markers (B10 and B11) polymorphic across strains of Epichloë endophyte.

Several things are noteworthy about these techniques. First, they are extremely timeand labor-intensive, requiring growth of seedlings, manual inoculation, microscopy, and multiple stages of processing. Second, they require an enormous amount of commercially produced laboratory equipment, including microscopes, slides, and chemical solutions for sterilization, staining, and protein detection. Notably, many of the QBIOgene FastDNA kits are branded and produced by American biotech companies for 
international markets. The potato dextrose agar is supplied by Difco Becton, Dickinson and Co. Third, detection methods rely on infrastructures of experimentation that depend on the continued exploitation of flora and fauna: here not simply host grasses, but small animals whose antibodies aid in the detection of fungi. For example, AgResearch uses an antibody for detecting endophytes developed using rabbits in Massey University's Small Animal Production unit.

Finally, the primary methods of detection are not new, but rather built on generations of scientific research. Growing out experimental plots is a practice standard to eighteenthcentury botanical gardens, and arguably to millennia of agricultural practice in less formal capacities. In the cereal endophyte program, wild relatives are grown out in containment facilities. Microscopy too is centuries old, and the models used in cereal endophyte research are old workhorses rather than state-of-the-art. The "Western blot," which distinguishes itself by the use of animal antibodies for protein detection, has been in use since the late 1970s. W. Neal Burnette devised this protein immunoblot while he was a postdoc at the Fred Hutchinson Cancer Center in Seattle, Washington. The name, and the method, was a play on the "Southern blot" method, devised by Ed Southern several years earlier in 1975. ${ }^{63}$ Immunoblots continue to be used in testing for a wide range of diseases, including hepatitis, Lyme disease, and HIV-AIDS. Such established methods of detection are still preferred to the identification of simple sequence repeats (SSRs), in spite of the attention to genetics in the practice of molecular biology.

How will networks of international research forged in relation to plant species change as the diversity of microorganisms becomes a target of investigation? According to a recent estimation by Hawksworth et al., there are "at least 1.5 million species" of fungi, and "probably more than 3 million." Other estimates indicate up to 5.1 million, only a handful of which are described. ${ }^{64}$ Fungal taxonomy has been upended by genomic sequencing analysis, putting phylogenetic hypotheses in flux. Fungi belong to two kingdoms in the Eukarya domain, but the movement of the kingdoms makes domain a more reliable criterion. Within the Eumycota kingdom in particular, there have been many recent changes, including the rise of a new phylum in 2001 and the dissolution of the "Zygomycota" based on genome scale comparisons (of 192 conserved proteins) ${ }^{65}$ Entirely new subphyla and classes are being identified using sequencing methods, as with active under-snow fungi and soil fungi constituting a new class within the Ascomycota. New research also suggests that Archaeorhizomycetes may be present in soil in forests and grasslands from the tundra to the tropics. ${ }^{66}$

\footnotetext{
${ }^{63}$ For an account of the Western blot's origins by its creator, see W. N. Burnette, "“Western blotting': Electrophoretic Transfer of Proteins from Sodium Dodecyl Sulfate-Polyacrylamide Gels to Unmodified Nitrocellulose and Radiographic Detection with Antibody and Radioiodinated Protein," Anal. Biochem. 112 (1981): 195-203.

${ }^{64}$ D. L. Hawksworth, "Global Species Numbers of Fungi: Are Tropical Studies and Molecular Approaches Contributing to a More Robust Estimate?," Biodiversity Conserv. 21 (2012): 2425-33.

${ }^{65}$ Joseph W. Spatafora, Ying Chang, Gerald L. Benny, Katy Lazarus, Matthew E. Smith, Mary L. Berbee, Gregory Bonito, et al., "A Phylum-Level Phylogenetic Classification of Zygomycete Fungi Based on Genome-Scale Data," Mycologia 108 (2016): 1028-46. A summary is provided by J. E. Stajich et al., "The Fungi," Curr. Biol. 19 (2009): R840-45.

${ }^{66}$ Christopher W. Schadt, Andrew P. Martin, David A. Lipson, and Steven K. Schmidt, "Seasonal Dynamics of Previously Unknown Fungal Lineages in Tundra Soils," Science 301 (2003): 1359-61; Anna Rosling, Filipa Cox, Karelyn Cruz-Martinez, Katarina Ihrmark, Gwen-Aëlle Grelet, Björn D. Lindahl, Audrius Menkis, and Timothy Y. James, "Archaeorhizomycetes: Unearthing an Ancient Class of Ubiquitous Soil Fungi," Science 333 (2011): 876-9.
} 
In spite of these possibilities, a much narrower conception of fungal diversity supports international agricultural research. The production of a select few commodities, including grain and meat, continue to drive research agendas. It is striking that the problem of morbidity in commercially raised cattle and sheep is what inspired researchers to disrupt the existing plant-host endophyte relationship in pasture grasses. Were it not for industry interest in growing fat ruminants, the relation between plant and fungus would have been considered stable and symbiotic, defending the plant against consumption by both insects and mammals. Endophytes have been detected in a range of wild relatives of modern cereals in the Triticeae tribe, but funders prioritizing wheat production are eager for more immediate progress directly related to the wheat plant. Wheat, along with maize and rice, represent the bulk of the global diet.

Unlike seed grain, which is the ultimate target product of cereal endophyte research, fungal endophytes themselves are not a perfect commodity. They resist reduction to experimental norms, requiring researchers to conduct time-consuming and laborious investigations toward their potential domestication. Grain is small, dry, and uniform, making it easily transported, exchanged, and preserved over long periods of time. Although there are different types and qualities of wheat, grading systems reduce these to standard values. There is a one-to-one correspondence between the input and product. These measures in turn facilitate the development of futures markets in grain, and the circulation of finance capital divorced from the material it represents. In short, staple grains earn an "A" grade for commensurability, the standard by which commodities are judged to be more or less perfect. ${ }^{67}$

Endophytes make less compliant subjects, exercising their own agency in the life cycle of the plant. The complexity of microbiological interactions resists imperatives of standardization fundamental to the commodity production of cereal crops, making them challenging objects of development. While the traits of common fungal endophytes are heritable, they nevertheless depend on the life cycle of the plant, living and dying with their hosts. Although they can select harmful and beneficial endophytes by isolating and culturing material from an infected plant, researchers do not understand all of the mechanisms conferring agronomic and ecological effects. Endophyte strains determine the type of secondary metabolite produced, while the host plant determines their quantity. But the behavior of endophytes appears to vary based on genotype and environmental conditions. Researchers are still working to understand these microorganisms and their overall symbiotic relationships with plants. On the whole, the cereal endophyte research process remains laborious and time-consuming, with the organic and symbiotic qualities of the plant-fungus relationship defying reduction to commodity form. Even as agriculture has reshaped global nutrient flows and metabolic capacities according to human selection, we cannot take for granted that contemporary biology can be reduced to the logics and processes of industrialization. ${ }^{68}$ For the

\footnotetext{
${ }^{67}$ On grading systems and futures markets, see William Cronon, Nature's Metropolis: Chicago and the Great West (New York, 1991); Jonathan Ira Levy, "Contemplating Delivery: Futures Trading and the Problem of Commodity Exchange in the United States, 1875-1905," Amer. Hist. Rev. 111 (2006): 307-35. On commensurability, see Wendy Nelson Espeland and Mitchell L. Stevens, "A Sociology of Quantification," Eur. J. Soc. 49 (2008): 401-36.

${ }^{68} \mathrm{On}$ the "biology of industrialization ... that hugely magnifies some metabolic capacities and feeds them onward, reshaping genomic time and space," see Landecker, "Antibiotic Resistance" (cit. n. 15). On genetics as a technology of modernization, see Thurtle, Emergence of Genetic Rationality (cit. n. 19); Fenzi and Bonneuil, "From 'Genetic Resources' to 'Ecosystems Services"” (cit. n. 23).
} 


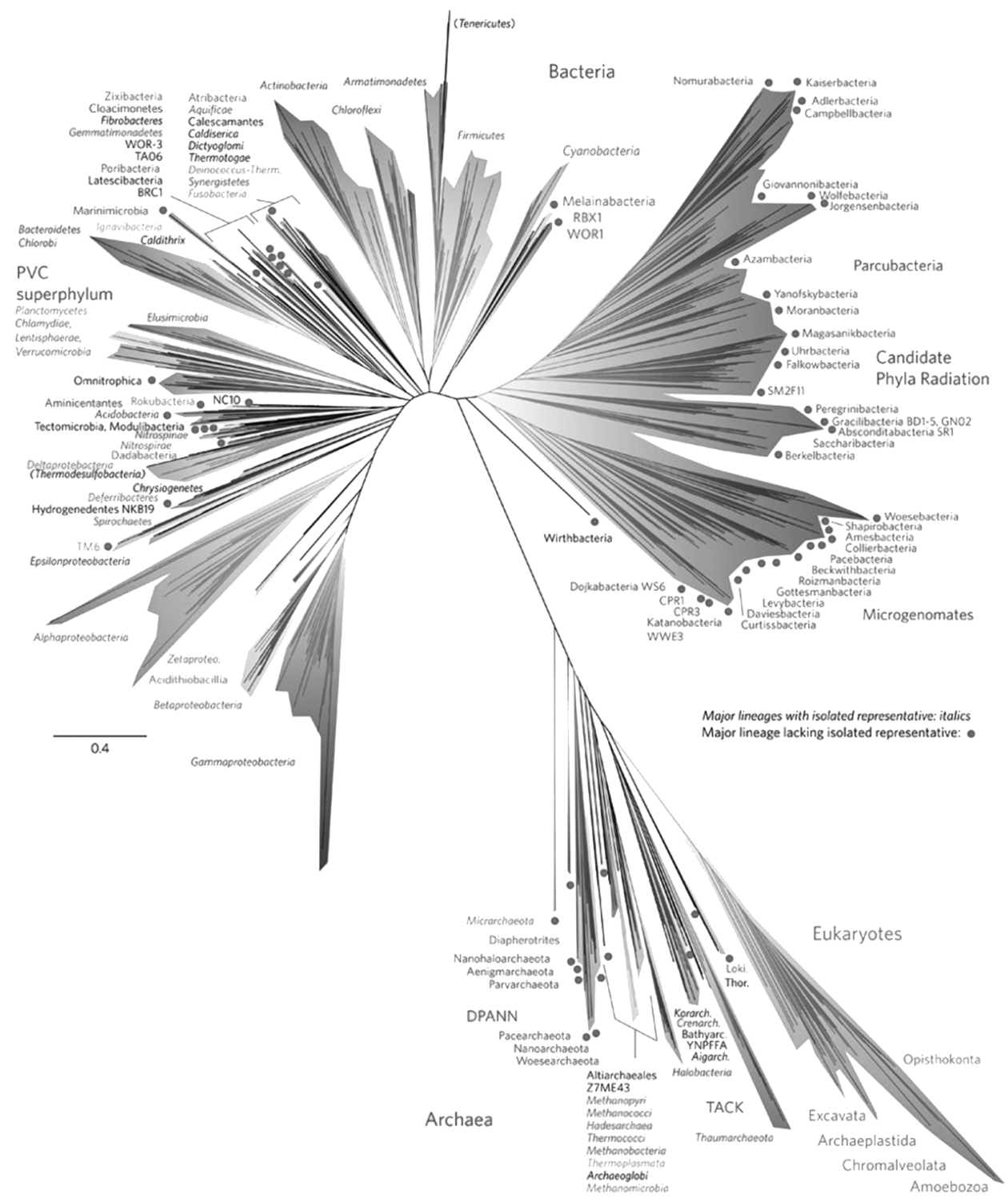

Figure 2. "A current view of the tree of life, encompassing the total diversity represented by sequenced genomes," from Laura A. Hug, Brett J. Baker, Karthik Anantharaman, Christopher T. Brown, Alexander J. Probst, Cindy J. Castelle, Cristina N. Butterfield et al., "A New View of the Tree of Life," Nature Microbiol. 1, article no. 16048, 11 April 2016, https://www.nature.com larticles/nmicrobiol201648\#f1.

moment, endophyte is not legible as a mechanism for harnessing the diversity of life (fig. 2).

\section{THE CAPITAL OF MICROBIOLOGICAL DIVERSITY}

If we inhabit a system in which the imperatives of capital delimit our imagination, and indeed the very forms of life on earth, it is worthwhile to understand how. Com- 
petition between nation-states abetted by imperial natural science gives us one framework for understanding capitalist development, based on commodification and the practices of science that supported it. In this view, the path dependency of current research is an outcome of an economic system that has for five centuries, as Jason Moore has recently argued, relied on "Cheap Nature" strategies that extract and exploit labor power, energy, food, and raw materials. ${ }^{69}$ Extractive agriculture entailed the broad geographic movement of plants, animals, and microbes and the intensification of production with resort to chemical fertilizers, precipitating what John Bellamy Foster has dubbed a "metabolic rift" between humans and their environments. ${ }^{70}$ This intensification of plant and animal energy precipitated a series of agricultural revolutions reconfiguring the global countryside in service of metropolitan growth, setting the stage for industrialization reliant on fossil fuel extraction. Intensified energy regimes unleashed continuous habitat destruction and biodiversity erosion that portend species extinction, including our own.

But we must also consider the ways that knowledge systems have abetted the exploitation of nature. These consist not merely of early modern European classificatory schemes and projects so thoroughly investigated by historians of science, but also a more protean array of microbiological techniques and investigations. When the activist Vandana Shiva opposed European and American patents on turmeric and neem, she decried not simply the economic impact of these practices on unindustrialized countries, but also the fundamental "theft of nature's creativity" they require. With other critics, she rejects not merely an inequitable distribution of resources, but a political economy of Western science that construes nature as a raw material for economic development. ${ }^{71}$ The charge of neo-imperialism is nevertheless an inadequate characterization of twenty-first-century science on both political economic and epistemological grounds. International networks of research capital may be products of empire, yet they are not identical to their antecedents, and understanding their operations requires approaches that eschew the nation-state and its archives as primary movers. Old categories of center and periphery obscure new networks of exchange intertwined with imperial legacies of removal and settlement and pursuing novel resources for profit.

Examining the values of biodiversity as an operational category in international agricultural research provides another view into this history and its outcomes. A critical history of biodiversity preservation should acknowledge its complex and contradictory array of logics and imperatives for environmental sanctity, poverty reduction, and growth. It should examine the technological, legal, and administrative apparatuses governing global plant genetic resources and identify the possibilities and limits of concepts in biodiversity, food security, and rural development as rubrics for political action and allocation of rights and resources on a global scale.

As they are currently framed, biodiversity preservation projects in international agricultural research can only tweak inputs to adapt to extremity: fabricating seed grain resistant to the biotic and abiotic stressors associated with climate change. When new aspects of biodiversity have become visible, it has been largely through observations,

\footnotetext{
${ }^{69}$ Jason W. Moore, Capitalism in the Web of Life: Ecology and the Accumulation of Capital (London, 2015).

${ }^{70}$ John Bellamy Foster, Marx's Ecology: Materialism and Nature (New York, 2000).

${ }^{71}$ Vandana Shiva, Biopiracy: The Plunder of Nature and Knowledge (Boston, 1997); Carolyn Merchant, The Death of Nature: Women, Ecology, and the Scientific Revolution (New York, 1980).
} 
investigations, and techniques of visualization and manipulation that prioritize human interests. In the context of agro-biodiversity, capitalized breeding interests fund collection that in turn preserves material for the use of researchers. The history of such investigations is thus a conceptual and a material one, constitutive of both our ideas about biological diversity and the very fabric of life on earth. Its analysis requires attention to political economy, scientific practice, and the imaginaries of life common to both.

Viewed through the periscope of microbiological diversity and buttressed by new methods in genome sequencing, eighteenth- and nineteenth-century taxonomies and geopolitical orderings seem to misrepresent the complexity, fluidity, and interdependence of life on earth. Biological metaphors of diversity and flow may be invoked to justify global reconfigurations of finance capital, masking continued reliance on the commodity form as the basis of profit accumulation. These reconfigurations, and the imaginaries that inform them, portend structures of governance beyond the nation-state as drivers of world capitalist development and call for new attention to the organization of mobile capital in the twenty-first century.

But there are other uses for biodiversity, including its ability to demonstrate alternative ways of organizing life to support mutuality and subsistence. Differently deployed, studies of biodiversity have the potential to dissolve whole taxonomies, as they have done for fungi, and to indict the commodity form as a primitive reduction of nature to human. To the extent that we need histories of economic thought attentive to its animating fictions, we also need analyses of the sciences that demonstrate how habits and assumptions harden into ideologies and technologies. To probe the possibilities and limits of science and capital as world-making instruments, we should consider not simply what the farmer knew about the ruminants, about the grass, about the fungus, about the soil, but also what the soil knew about the fungus, about the grass, about the ruminants, about the farmer. 